\title{
Pharmacodynamics of mefloquine and praziquantel combination therapy in mice harbouring juvenile and adult Schistosoma mansoni
}

\author{
Naglaa Mohamed El-Lakkany ${ }^{1 /+}$, Sayed Hassan Seif el-Din', \\ Abdel-Nasser Abdel-Aal Sabra', Olfat Ali Hammam² \\ 'Department of Pharmacology ${ }^{2}$ Department of Pathology, \\ Theodor Bilharz Research Institute, Warak El-Hadar, Imbaba PO Box 30, Giza 12411, Egypt
}

\begin{abstract}
Praziquantel (PZQ) is currently the only drug widely used for the treatment of schistosomiasis, but the antimalarial drug mefloquine (Mef) possesses interesting antischistosomal properties. Combination therapy with these two drugs has been suggested as a strategy for transmission control, as PZQ is active against adult worms and Mef is active against schistosomula. To examine the efficacy of combination therapy, Schistosoma mansoni-reinfected mice were separated into seven groups: untreated (I), treated with PZQ in doses of $200 \mathrm{mg} / \mathrm{kg}$ (II) or 1,000 mg/kg (III), treated with Mef in doses of $200 \mathrm{mg} / \mathrm{kg}$ (IV) or $400 \mathrm{mg} / \mathrm{kg}$ (V); each dose was divided equally and given on two consecutive days. Group VI was treated with doses of PZQ + Mef as in groups II and IV, respectively, while group $V I I$ was treated with $P Z Q+$ Mef as in groups III and V, respectively. PZQ + Mef at the reduced doses of $200 \mathrm{mg} / \mathrm{kg}$ each enhanced the therapeutic efficacy over the reduced PZQ dose alone as shown by a very high reduction in the total numbers of mature worms (95\% vs. 49\%), immature worms (96\% vs. $29 \%$ ) and the complete eradication of immature females, mature females and immature eggs. The reduction in worm burden was associated with the healing of hepatic granulomatous lesions and the normalisation of all liver enzymes. Therefore, the use of Mef with PZQ is more effective than PZQ alone and should be considered for clinical trials in humans as a potential treatment regimen to prevent treatment failures in areas with high rates of schistosomiasis.
\end{abstract}

Key words: Schistosoma mansoni - praziquantel - mefloquine - reinfection - therapeutic efficacy

Schistosomiasis remains a major health problem in many tropical areas. It is currently estimated that over 200 million people are infected and nearly 800 million others are at risk of infection. Schistosomiasis causes 280,000 deaths annually and more than 20 million individuals experience high morbidity from the disease (King et al. 2005, Steinmann et al. 2006, Sayed et al. 2008). Praziquantel (PZQ) is currently the drug of choice for the treatment of schistosomiasis, but its widespread use has led to concern that the emergence of PZQ-resistant schistosomes may eventually render it obsolete (Botros \& Bennett 2007, Caffrey 2007). However, it is unclear whether schistosomes have developed clinically relevant levels of resistance to PZQ. Botros et al. (2005) has cast some doubt on previous reports of resistance (Ismail et al. 1996, 1999) because no significant resistance was observed in the same region after 10 years of therapeutic pressure. While the likelihood of the development and spread of PZQ resistance is uncertain, the slightest possibility of resistance occurring reinforces the need for alternative treatments.

Financial support: TBRI

+ Corresponding author: naglaaellakkany@yahoo.com

Received 5 April 2011

Accepted 10 October 2011
Various studies have sought to identify new drugs to use as alternatives to PZQ or in conjunction with PZQ (Fenwick \& Webster 2006, Abdulla et al. 2007, Caffrey 2007, Keiser \& Utzinger 2007, Xiao et al. 2007, Sayed et al. 2008). Several promising leads have been identified, including analogues of the antimalarial artemisinin and the synthetic derivatives trioxane and trioxolane (Caffrey 2007, Keiser \& Utzinger 2007). The artemisinins artemether and artesunate, which are essential components of malaria treatment and control (White 2008), also possess antischistosomal properties (Xiao et al. 2000, Seif el-Din 2007, Utzinger et al. 2007). Detailed in vivo studies revealed that schistosomula are particularly susceptible to the artemisinins and that a moderate reduction in worm burden can still be achieved for adult worms (Xiao et al. 2002). A number of clinical trials carried out in different African settings confirmed that both artemether and artesunate are effective against Schistosoma haematobium and Schistosoma mansoni infections (Keiser \& Utzinger 2007, Utzinger et al. 2007). Interestingly, the antimalarial drug mefloquine (Mef) and its analogues have also been shown to have schistosomicidal activity (Keiser et al. 2009). Any shared mechanism of action that underlies the effects of the artemisinins and Mef on schistosomes and malaria parasites is still unclear.

Egypt has employed PZQ-based chemotherapy to control schistosomiasis at the community level and has sustained a national control program for a prolonged period and an impressive reduction in morbidity has been achieved (WHO 2000). The renewed impetus for extend- 
ing schistosomiasis control throughout sub-Saharan Africa will likely rely on a greater use of PZQ than ever before (Engels 2002, Fenwick 2003). However, despite the success in controlling schistosomiasis with PZQ, there is a significant deficiency in the therapeutic profile of PZQ; the drug targets the adult worm but has only minor activity against the young developing stages (schistosomula) (Doenhoff et al. 2008, Keiser et al. 2009). Therefore, a second treatment with PZQ is necessary to kill any parasites that matured after the first treatment. The need for retreatment presents an economic burden to poorer nations that will require external support to allow them to prioritise the control of schistosomiasis. Even with retreatment, the peculiar stage-specificity of PZQ means that some immature parasites will remain unaffected by the drug. These parasites can later mature to egg-producing adult worms and thus lead to apparent treatment failure. Treatment failure occurs most often in areas of high transmission and in individuals harbouring large numbers of maturing worms that escape the effects of PZQ (Sabah et al. 1986). It is possible that drug combinations could prove useful by offsetting the shortcomings of individual agents (such as stage or species-dependence). Combination therapy may also provide mutual protection against the development of resistance (Geary et al. 2010).

It should also be recognised that the use of artemisinin analogues and perhaps Mef, for the treatment of malaria might have additional benefits in areas that are also endemic for schistosomiasis (Keiser \& Utzinger 2007, Keiser et al. 2009). A preliminary study by Xiao et al. (2011) on a Mef/PZQ combination therapy revealed that treating Schistosoma japonicum-infected mice with each of Mef or PZQ alone at single dose of $50 \mathrm{mg} / \mathrm{kg}$ has no apparent improvement in efficacy relative to that of the untreated infected control. The authors added that increasing the dose of both drugs to $100 \mathrm{mg} / \mathrm{kg}$ resulted in a statistically significant difference in female worm burdens between the PZQ group and combined treatment group. Moreover, Mef exhibits a direct killing effect against adult and juvenile $S$. japonicum in vitro, but juvenile schistosomes are more susceptible to in vitro exposure to Mef than the adult worms (Xiao et al. 2009). In this study, we tested the potential of Mef/PZQ combination therapy in two dose regimens in animals harbouring both immature and mature $S$. mansoni worms by examining parasitological criteria of cure represented by worm burden and distribution, tissue egg load and oogram pattern. The histopathology and function of the livers of the infected and uninfected animals after treatment were also investigated.

\section{MATERIALS AND METHODS}

Drugs and doses - Mef $\mathrm{HCl}\left(\right.$ Mephaquin $\left.^{\circledR}\right)$ tablets were obtained (Mepha Ltd, Aesch-Basel, Switzerland, lot 0850074$)$ and were administered orally as a fresh suspension in $7 \%(\mathrm{v} / \mathrm{v})$ Tween- 80 and $3 \%(\mathrm{v} / \mathrm{v})$ ethanol. Mef was administered as a high dose of $400 \mathrm{mg} / \mathrm{kg}$ or a reduced dose of $200 \mathrm{mg} / \mathrm{kg}$ (Keiser et al. 2009); each dose was divided in half and given on two consecutive days. PZQ tablets (Distocide ${ }^{\circledR}$, EIPICO, El-Asher Men Ramadan, Egypt) were administered orally as a suspension in $2 \%$ cremophore-El (Sigma-Aldrich Chemical Co, St. Louis, MO) in a high dose of $1,000 \mathrm{mg} / \mathrm{kg}$ (Gonnert \& Andrews 1977) or a reduced dose of $200 \mathrm{mg} / \mathrm{kg}$ (Fallon $\&$ Doenhoff 1995), which were also divided in half and given on two consecutive days.

Animals - One hundred and twelve male CD1 Swiss albino mice, average weight of $20 \mathrm{~g} \pm 2$, were bred and maintained at the Schistosome Biology Supply Center (SBSC) of Theodor Bilharz Research Institute (TBRI), Giza, Egypt. Animals were housed in a controlled temperature and light environment and were given water and commercial chow ad libitum. The animal experiments were conducted in the animal unit according to the international ethical guidelines after approval by the Institutional Review Board of TBRI.

Infection of animals - Cercariae of S. mansoni (Egyptian strain) were obtained from infected intermediate host snails maintained at the SBSC. Animals were infected with $80 \pm 10$ cercariae/mouse using the body immersion technique (Liang et al. 1987) and then reinfected 35 days after the first infection with $40 \pm 5$ cercariae/mouse.

Animal groups - Reinfected, untreated mice (I), reinfected mice treated with PZQ at a reduced dose of $200 \mathrm{mg} / \mathrm{kg}$ divided equally and administered on two consecutive days (II), reinfected mice treated with PZQ at a high dose of $1,000 \mathrm{mg} / \mathrm{kg}$ divided equally and administered on two consecutive days (III); reinfected mice treated with Mef at a reduced dose of $200 \mathrm{mg} / \mathrm{kg}$ divided equally and administered on two consecutive days (IV), reinfected mice treated with Mef at a high dose of $400 \mathrm{mg} / \mathrm{kg}$ divided equally and administered on two consecutive days $(\mathrm{V})$, reinfected mice treated concomitantly with the reduced doses of both PZQ and Mef as in groups II and IV, respectively (VI), and reinfected mice treated concomitantly with the high doses of both PZQ and Mef as in groups III and V, respectively (VII).

Animals in all infected groups were treated with both Mef and PZQ 49 days after the first infection (14 days post reinfection) and were killed by rapid decapitation nine weeks after the first infection (28 days post reinfection). Comparable groups of uninfected mice were subjected to the same treatment schedule to evaluate the safety of PZQ/Mef combination therapy. After decapitation, blood was collected and sera were separated by centrifugation at $1,850 \mathrm{~g}$ for $10 \mathrm{~min}$ and stored frozen at $-70^{\circ} \mathrm{C}$.

Assessment of parasitological criteria - To recover mature and immature worms for subsequent counting and determination of sex, the hepatic and mesenteric vessels of infected animals were perfused according to Duvall and De Witt (1967) without using general anaesthesia. The number of ova per gram of liver or intestinal tissue (tissue egg load) was counted according to the method of Cheever (1968) in which a piece of small intestinal or hepatic tissue was weighed before digestion in $5 \% \mathrm{KOH}$. The percentage of eggs in the different developmental stages (oogram pattern) was studied according to the method of Pellegrino et al. (1962), in which eggs at different stages of maturity were identified (from I-IV) according to the size of the embryo and 
were counted. In addition, mature eggs containing fully developed miracidium and dead eggs (granular, dark and semi-transparent) from three fragments of the small intestine were counted and the mean numbers of eggs each stage were calculated.

Histopathology and granuloma measurement - Livers were harvested from the mice, fixed in $10 \%$ buffered formalin and processed to paraffin blocks. Sections $(4 \mu \mathrm{m}$ thick) were cut every $250 \mu \mathrm{m}$ to avoid measuring the same granuloma. Five liver sections were prepared from each animal and stained with the haematoxylin and eosin and Masson trichrome stains. Measurements of the granulomas were conducted on non-contiguous granulomas, each containing a single egg (with intact or degenerated miracidia), using an ocular micrometre. The mean diameter of each granuloma was calculated by measuring two diameters of the lesion at right angles to each other (Von Lichtenberg 1962). Thirty granulomas were measured from each mouse. Granuloma structural configurations, including cellular components and associated hepatic histopathological changes, were studied and the percentages of viable and dead eggs were also calculated.

Serum enzymes - The concentrations of alanine aminotransferase (ALAT), total proteins, albumin and urea in the collected sera were estimated using the available commercial kits.

Statistical analysis - Results were analysed with the use of the Statistical Package for the Social Sciences software (version 9.0). The values are expressed as the means \pm standard error of the mean. The means of groups were compared with the use of an unpaired $t$-test.
For comparisons of more than two groups, an Analysis of Variance test was used. Data were considered significant at a $\mathrm{p}$ value $<0.05$.

\section{RESULTS}

Parasitological studies - Table I shows that administering Mef to $S$. mansoni-reinfected mice in split oral doses of $200 \mathrm{mg} / \mathrm{kg}$ or $400 \mathrm{mg} / \mathrm{kg}$ for two consecutive days significantly $(\mathrm{p}<0.001)$ reduced the numbers of immature male worms, immature female worms and total immature worms by $61.4 \%$ and $84.2 \%, 74.8 \%$ and $96.8 \%$ and $67.4 \%$ and $89.9 \%$, respectively, compared with the untreated reinfected group. Mef administration at the above doses also significantly reduced the number of mature males, mature females and total mature worms by $28.3 \%(\mathrm{p}<0.01)$ and $56.7 \%(\mathrm{p}<0.001), 57.6 \%$ and $80.3 \%$ $(\mathrm{p}<0.001)$ and $41.9 \%(\mathrm{p}<0.01)$ and $67.7 \%(\mathrm{p}<0.001)$, respectively. Moreover, significant decreases in the hepatic $(28.7 \%, \mathrm{p}<0.05$ and $50.9 \%, \mathrm{p}<0.001$, respectively) and intestinal ( $79.8 \%$ and $87.5 \%, \mathrm{p}<0.001$, respectively) tissue egg loads and in the percentage of immature eggs concomitant with a significant increase $(p<0.001)$ in the percentage of dead eggs were observed (Table II).

Administering PZQ in split oral doses of $200 \mathrm{mg} / \mathrm{kg}$ or $1,000 \mathrm{mg} / \mathrm{kg}$ to $S$. mansoni-reinfected mice for two consecutive days significantly reduced the numbers of immature males, immature females and total immature worms by $31.1 \%(\mathrm{p}<0.05)$ and $48.2 \%(\mathrm{p}<0.001), 18.5 \%$ $(p>0.05)$ and $43.7 \%(p<0.01)$ and $29.2 \%$ and $46.2 \%$ $(\mathrm{p}<0.001)$, respectively, compared with the untreated S. mansoni-reinfected group. PZQ administration at the above doses also significantly reduced the total mature males, females and total mature worms by $55.2 \%$ and

TABLE I

Effect of mefloquine (Mef) with/without praziquantel (PZQ) on total males, females and total worms nine weeks post-infection (i.e. 2 weeks post-treatment) in mice reinfected with Schistosoma mansoni

\begin{tabular}{|c|c|c|c|c|c|c|}
\hline \multirow[b]{2}{*}{ Animal groups } & \multicolumn{2}{|c|}{ Total males } & \multicolumn{2}{|c|}{ Total females } & \multicolumn{2}{|c|}{ Total worms } \\
\hline & Mature & Immature & Mature & Immature & Mature & Immature \\
\hline Infected untreated & $10.89 \pm 0.42$ & $5.44 \pm 0.53$ & $9.44 \pm 0.88$ & $4.44 \pm 0.38$ & $20.34 \pm 1.13$ & $9.89 \pm 0.79$ \\
\hline $\begin{array}{l}\text { Inf + PZQ } \\
(200 \mathrm{mg} / \mathrm{kg})\end{array}$ & $\begin{array}{l}4.88 \pm 0.69^{c} \\
\quad(55.2)\end{array}$ & $\begin{array}{l}3.37 \pm 0.46^{a} \\
\quad(38.1)\end{array}$ & $\begin{array}{l}5.38 \pm 0.92^{b} \\
(43)\end{array}$ & $\begin{array}{l}3.62 \pm 0.37 \\
\quad(18.5)\end{array}$ & $\begin{array}{l}10.25 \pm 1.42^{c} \\
\quad(49.6)\end{array}$ & $\begin{array}{l}7.00 \pm 0.46^{b} \\
(29.2)\end{array}$ \\
\hline $\begin{array}{l}\text { Inf + PZQ } \\
(1,000 \mathrm{mg} / \mathrm{kg})\end{array}$ & $\begin{array}{l}0.36 \pm 0.26^{c} \\
\quad(96.6)\end{array}$ & $\begin{array}{l}2.82 \pm 0.29^{c} \\
\quad(48.2)\end{array}$ & $\begin{array}{l}1.12 \pm 0.35^{c} \\
\quad(88.1)\end{array}$ & $\begin{array}{l}2.50 \pm 0.39^{b} \\
\quad(43.7)\end{array}$ & $\begin{array}{l}1.49 \pm 0.20^{c} \\
\quad(92.6)\end{array}$ & $\begin{array}{l}5.32 \pm 0.36^{c} \\
\quad(46.2)\end{array}$ \\
\hline $\begin{array}{l}\text { Inf }+ \text { Mef } \\
(200 \mathrm{mg} / \mathrm{kg})\end{array}$ & $\begin{array}{l}7.81 \pm 0.89^{b} \\
\quad(28.3)\end{array}$ & $\begin{array}{l}2.10 \pm 0.20^{c} \\
\quad(61.4)\end{array}$ & $\begin{array}{l}4.00 \pm 0.59^{c} \\
\quad(57.6)\end{array}$ & $\begin{array}{l}1.12 \pm 0.51^{c} \\
\quad(74.8)\end{array}$ & $\begin{array}{l}11.81 \pm 2.95^{b} \\
\quad(41.9)\end{array}$ & $\begin{array}{l}3.22 \pm 0.68^{c} \\
\quad(67.4)\end{array}$ \\
\hline $\begin{array}{l}\text { Inf + Mef } \\
(400 \mathrm{mg} / \mathrm{kg})\end{array}$ & $\begin{array}{l}4.71 \pm 1.63^{c} \\
\quad(56.7)\end{array}$ & $\begin{array}{l}0.86 \pm 0.55^{c} \\
(84.2)\end{array}$ & $\begin{array}{l}1.86 \pm 0.26^{c} \\
\quad(80.3)\end{array}$ & $\begin{array}{l}0.14 \pm 0.14^{c} \\
\quad(96.8)\end{array}$ & $\begin{array}{l}6.57 \pm 1.84^{c} \\
\quad(67.7)\end{array}$ & $\begin{array}{l}1.00 \pm 0.65^{c} \\
(89.9)\end{array}$ \\
\hline $\begin{array}{l}\text { Inf + Mef + PZQ } \\
(200 \mathrm{mg} / \mathrm{kg}+200 \mathrm{mg} / \mathrm{kg})\end{array}$ & $\begin{array}{l}0.67 \pm 0.23^{c, d} \\
\quad(93.8)\end{array}$ & $\begin{array}{l}0.33 \pm 0.16^{c, d} \\
\quad(93.9)\end{array}$ & $\begin{array}{l}0.22 \pm 0.14^{c, d} \\
\quad(97.7)\end{array}$ & $\begin{array}{l}0.00 \pm 0.00^{c, d} \\
\quad(100)\end{array}$ & $\begin{array}{l}0.89 \pm 0.31^{c, d} \\
\quad(95.6)\end{array}$ & $\begin{array}{l}0.33 \pm 0.17^{c, d} \\
\quad(96.7)\end{array}$ \\
\hline $\begin{array}{l}\text { Inf }+ \text { Mef + PZQ } \\
(400 \mathrm{mg} / \mathrm{kg}+1,000 \mathrm{mg} / \mathrm{kg})\end{array}$ & $\begin{array}{l}0.37 \pm 0.18^{c, e} \\
\quad(96.6)\end{array}$ & $\begin{array}{l}0.25 \pm 0.16^{c, e} \\
\quad(95.4)\end{array}$ & $\begin{array}{l}0.00 \pm 0.00^{c, e, f} \\
\quad(100)\end{array}$ & $\begin{array}{l}0.00 \pm 0.00^{c, e} \\
(100)\end{array}$ & $\begin{array}{l}0.37 \pm 0.18^{c, e} \\
\quad(98.2)\end{array}$ & $\begin{array}{l}0.25 \pm 0.16^{c, e} \\
\quad(97.4)\end{array}$ \\
\hline
\end{tabular}

$a: \mathrm{p}<0.05 ; b: \mathrm{p}<0.01 ; c: \mathrm{p}<0.001$ vs. infected (Inf) untreated; $d: \mathrm{p}<0.001$ vs. PZQ $(200 \mathrm{mg} / \mathrm{kg}) ; e: \mathrm{p}<0.001$ vs. PZQ (1,000 $\mathrm{mg} / \mathrm{kg}) ; f: \mathrm{p}<0.001 \mathrm{vs}$. PZQ $+\operatorname{Mef}(200 \mathrm{mg} / \mathrm{kg}+200 \mathrm{mg} / \mathrm{kg})$. Number of animals in each group: eight mice. Values are presented as mean \pm standard error of the mean. Numbers between parentheses indicate the percentage of reduction from infected untreated. 
96.6\% $(\mathrm{p}<0.001), 43 \%(\mathrm{p}<0.01)$ and $88.1 \%(\mathrm{p}<0.001)$ and $49.6 \%$ and $92.6 \%(\mathrm{p}<0.001)$, respectively (Table I). This was accompanied by significant decreases in the hepatic $(41.5 \%, \mathrm{p}<0.05$ and $77.9 \%, \mathrm{p}<0.001)$ and intestinal $(84.3 \%$ and $94.2 \%, \mathrm{p}<0.001)$ tissue egg loads, respectively, and in the percentage of immature eggs and a significant increase $(p<0.001)$ in the percentage of dead eggs was also found (Table II).

The co-administration of PZQ and Mef in both reduced and high doses significantly enhanced $(p<0.001)$ the killing of immature and mature males, immature and mature females and total immature and mature worms and also reduced hepatic $(p<0.05 ; p<0.001)$ and intestinal $(\mathrm{p}<0.001)$ tissue egg burdens when compared with S. mansoni-reinfected groups treated with PZQ alone at either dose. Treatment of reinfected mice with PZQ + Mef at the reduced doses killed all immature females, while treatment with the high doses of each drug killed all mature and immature females. This was accompanied by a complete loss of immature eggs and an increase in the percentage of dead eggs (94.22\% and $99.25 \%)$ in the groups treated with PZQ + Mef in reduced or high doses, respectively (Tables I, II). No remarkable differences were observed between the groups treated with reduced doses of PZQ + Mef and the groups treated with high doses of PZQ + Mef in most of the assessed parameters.

Histopathological studies - Liver sections of untreated and treated uninfected mice showed normal hepatic lobular architecture with hepatocytes arranged in thin plates. The portal tracts were within normal limits and contained arteries, veins and bile ducts. The hepatocytes contained rounded, regular nuclei with lymphocytes scattered between hepatocytes and the sinusoids. Moreover, no hydropic, steatotic, feathery or ballooning changes, degeneration or apoptosis were observed (Fig. 1A-E). Only scattered or focal collections of lymphocytes in between hepatocytes (focal spotty necrosis) were observed in liver sections of uninfected mice treated with either Mef alone at high dose (Fig. 1C) or combined with PZQ at high dose (Fig. 1E).

Liver sections from $S$. mansoni-reinfected mice killed nine weeks after the first infection (28 days post reinfection) showed a typical large fibrocellular granuloma centred around living ova, including living miracidium and surrounded by lymphocytes, epithelioid cells, eosinophils, polymorphonuclear cells and fibrous tissue (Fig. $2 \mathrm{~A})$. Compared to the reinfected untreated group, treatment with PZQ or Mef alone reduced the diameters of the granulomas by $28.08 \%$ and $26.26 \%(p<0.01)$, respectively, with the reduced doses of each drug and reduced granuloma diameters by $39.39 \%$ and $32.53 \%(\mathrm{p}<0.001)$, respectively, with the higher concentration of each drug (Fig. 2B-E, Table III). Moreover, we observed a significant reduction in the granuloma diameters in groups treated with PZQ + Mef at the reduced dose $(p<0.01)$ or high dose $(\mathrm{p}<0.05)$ in comparison with groups treated with the different doses of PZQ alone (Fig. 2F, G, Table III). All treated groups showed size-variable, well-demarcated or circumscribed fibrocellular granulomas with central ova encircling living or dead miracidia, surrounded by lymphocytes, epithelioid cells, neutrophils, eosinophils and collagen bundles. All treatment regimens signifi-

TABLE II

Effect of mefloquine (Mef) with/without praziquantel (PZQ) on percentage egg developmental stages and tissue egg load nine weeks post-infection (i.e. 2 weeks post-treatment) in mice reinfected with Schistosoma mansoni

\begin{tabular}{|c|c|c|c|c|c|}
\hline \multirow[b]{2}{*}{ Animal groups } & \multicolumn{3}{|c|}{ Percentage egg developmental stages } & \multicolumn{2}{|c|}{ Tissue egg load $\times 10^{3}$} \\
\hline & $\begin{array}{l}\text { Immature } \\
(\%)\end{array}$ & $\begin{array}{l}\text { Mature } \\
(\%)\end{array}$ & $\begin{array}{l}\text { Dead } \\
(\%)\end{array}$ & Hepatic & Intestinal \\
\hline Infected untreated & $57.09 \pm 2.80$ & $33.45 \pm 2.48$ & $9.45 \pm 0.72$ & $11.48 \pm 0.93$ & $19.05 \pm 1.77$ \\
\hline $\begin{array}{l}\text { Inf + PZQ } \\
(200 \mathrm{mg} / \mathrm{kg})\end{array}$ & $2.50 \pm 2.50^{c}$ & $13.13 \pm 3.40^{c}$ & $84.38 \pm 4.77^{c}$ & $\begin{array}{l}6.72 \pm 1.95^{a} \\
(41.5)\end{array}$ & $\begin{array}{l}2.99 \pm 0.31^{c} \\
(84.3)\end{array}$ \\
\hline $\begin{array}{l}\text { Inf + PZQ } \\
(1,000 \mathrm{mg} / \mathrm{kg})\end{array}$ & $0.00 \pm 0.00^{c}$ & $3.88 \pm 1.01^{c}$ & $96.13 \pm 1.01^{c}$ & $\begin{array}{l}2.54 \pm 0.22^{c} \\
\quad(77.9)\end{array}$ & $\begin{array}{l}1.11 \pm 0.10^{c} \\
(94.2)\end{array}$ \\
\hline $\begin{array}{l}\text { Inf }+ \text { Mef } \\
(200 \mathrm{mg} / \mathrm{kg})\end{array}$ & $2.50 \pm 0.94^{c}$ & $30.25 \pm 4.70$ & $67.25 \pm 4.60^{c}$ & $\begin{array}{l}8.18 \pm 1.08^{a} \\
\quad(28.7)\end{array}$ & $\begin{array}{l}3.84 \pm 0.44^{c} \\
\quad(79.8)\end{array}$ \\
\hline $\begin{array}{l}\operatorname{Inf}+\mathrm{Mef} \\
(400 \mathrm{mg} / \mathrm{kg})\end{array}$ & $0.71 \pm 0.71^{c}$ & $15.00 \pm 4.08^{b}$ & $84.29 \pm 4.00^{c}$ & $\begin{array}{l}5.65 \pm 0.82^{c} \\
(50.9)\end{array}$ & $\begin{array}{l}2.37 \pm 0.25^{c} \\
(87.5)\end{array}$ \\
\hline $\begin{array}{l}\text { Inf }+ \text { Mef }+ \text { PZQ } \\
(200 \mathrm{mg} / \mathrm{kg}+200 \mathrm{mg} / \mathrm{kg})\end{array}$ & $0.00 \pm 0.00^{c, e}$ & $5.78 \pm 3.09^{c}$ & $94.22 \pm 3.09^{c}$ & $\begin{array}{c}1.81 \pm 0.23^{c, d} \\
(84.2)\end{array}$ & $\begin{array}{l}0.56 \pm 0.07^{c, e} \\
\quad(97.1)\end{array}$ \\
\hline $\begin{array}{l}\mathrm{Inf}+\mathrm{Mef}+\mathrm{PZQ} \\
(400 \mathrm{mg} / \mathrm{kg}+1,000 \mathrm{mg} / \mathrm{kg})\end{array}$ & $0.00 \pm 0.00^{c, g}$ & $0.75 \pm 0.41^{c, f}$ & $99.25 \pm 0.41^{c}$ & $\begin{array}{c}0.88 \pm 0.13^{c, g, h} \\
\quad(92.3)\end{array}$ & $\begin{array}{l}0.48 \pm 0.07^{c, g} \\
\quad(97.5)\end{array}$ \\
\hline
\end{tabular}

$a: \mathrm{p}<0.05 ; b: \mathrm{p}<0.01 ; c: \mathrm{p}<0.001$ vs. infected (Inf) untreated; $d: \mathrm{p}<0.05 ; e: \mathrm{p}<0.001 \mathrm{vs}$. PZQ $(200 \mathrm{mg} / \mathrm{kg}) ; f: \mathrm{p}<0.05 ; g: \mathrm{p}<$ 0.001 vs. PZQ $(1,000 \mathrm{mg} / \mathrm{kg}) ; h: \mathrm{p}<0.01 \mathrm{vs}$. PZQ $+\operatorname{Mef}(200 \mathrm{mg} / \mathrm{kg}+200 \mathrm{mg} / \mathrm{kg})$. Number of animals in each group: eight mice. Values are presented as mean \pm standard error of the mean. Numbers between parentheses indicate the percentage of reduction from infected untreated. 
cantly increased $(p<0.01)$ the percentage of dead ova in the examined liver sections compared to the infected untreated group. Moreover, the percentage of ova degeneration was significantly increased in the liver sections from groups treated with PZQ + Mef at the reduced $(p<0.05)$ or high $(\mathrm{p}<0.01)$ doses when compared to PZQ alone at its reduced or high dose, respectively (Table III).

Enzyme assessments - Treatment of uninfected mice with PZQ, Mef or PZQ + Mef at the reduced and high doses did not alter the enzyme levels, which were measured to assess liver and kidney function (Table IV). Reinfection of mice with $S$. mansoni significantly increased serum levels of ALAT $(p<0.001)$ and significantly decreased the levels of albumin $(p<0.001)$ and
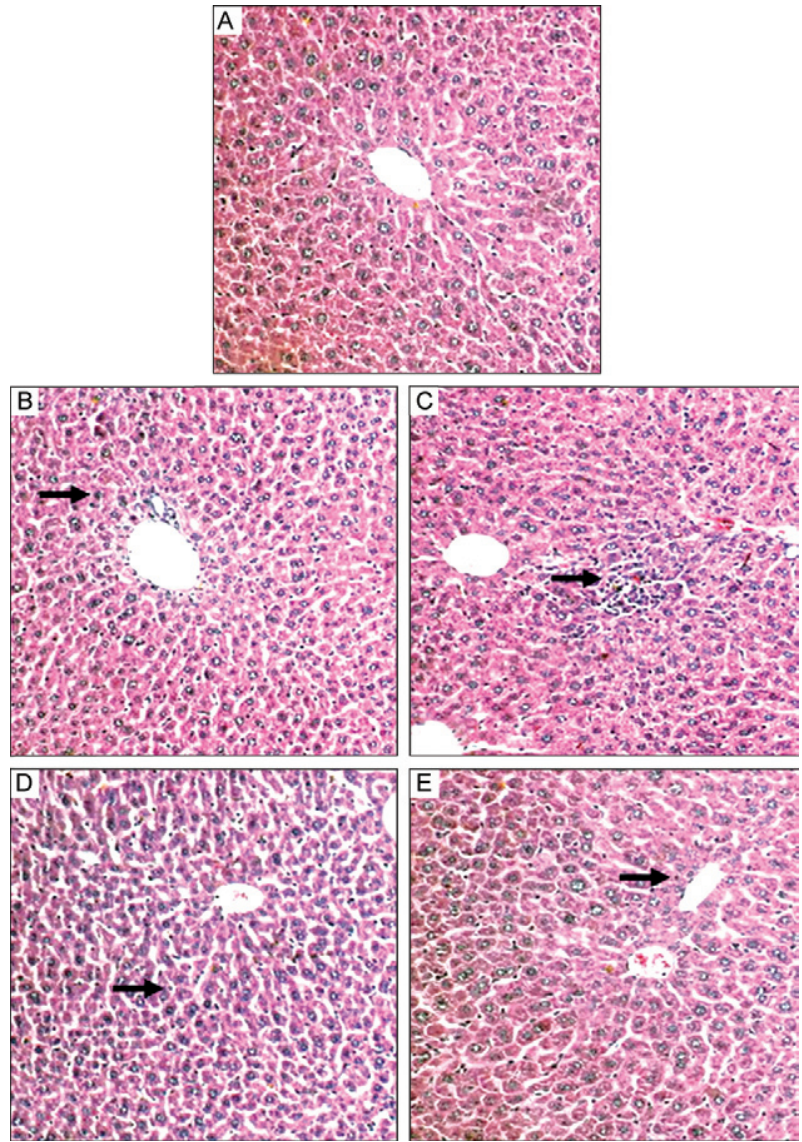

Fig. 1: liver sections from (A) uninfected untreated mouse showing normal hepatic architecture and normal hepatocytes; B: uninfected treated with praziquantel (PZQ) $(1,000 \mathrm{mg} / \mathrm{kg})$ showing normal hepatic architecture and normal hepatocytes with scattered lymphocytes in between hepatocytes and in the sinusoids; C: uninfected treated with mefloquine (Mef) $(400 \mathrm{mg} / \mathrm{kg}$ ) showing normal hepatic architecture and normal hepatocytes with focal spotty necrosis (collected lymphocytes in between hepatocytes); D: uninfected treated with Mef $(200 \mathrm{mg} / \mathrm{kg})+$ PZQ $(200 \mathrm{mg} / \mathrm{kg})$ showing normal hepatic architecture and normal hepatocytes with slightly scattered lymphocytes in between hepatocytes and in the sinusoids; E: uninfected treated with Mef $(400 \mathrm{mg} / \mathrm{kg})+$ PZQ $(1,000 \mathrm{mg} / \mathrm{kg})$ showing normal hepatic architecture and normal hepatocytes with moderate scattered lymphocytes in between hepatocytes and in the sinusoids (200X). total protein $(\mathrm{p}<0.01)$ and the albumin/globulin $(\mathrm{A} / \mathrm{G})$ ratio $(\mathrm{p}<0.05)$ in comparison with the uninfected untreated group. Compared to reinfected untreated group, the ALAT level was significantly decreased in the groups treated with either PZQ $(p<0.01, p<0.001)$ or Mef
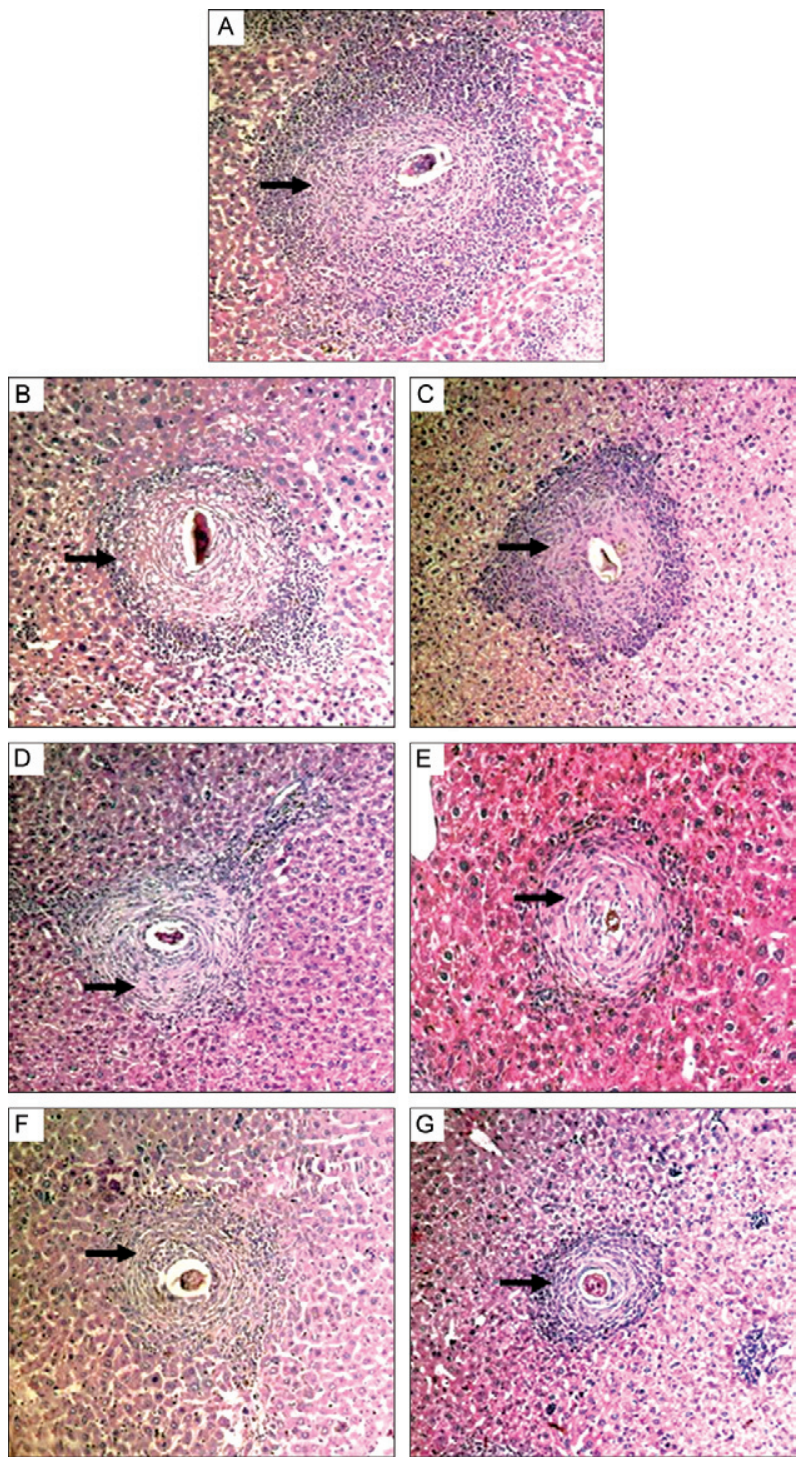

Fig. 2: haematoxylin and eosin stained liver sections of (A) infected untreated mice ( 9 weeks post-infection) showing irregularly outlined large fibrocellular granuloma consisting of collagenous fibrous tissue surrounding one living intact ova and peripheral zone of chronic inflammatory cells; B-C: infected treated with praziquantel (PZQ) or mefloquine (Mef) $(200 \mathrm{mg} / \mathrm{kg})$ respectively showing medium sized fibrocellular granuloma with starting ova degeneration; D: infected treated with PZQ $(1,000 \mathrm{mg} / \mathrm{kg})$ showing medium circumscribed fibrocellular granuloma with more ova degeneration; E: infected treated with Mef $(400 \mathrm{mg} / \mathrm{kg})$ showing medium sized fibrocellular granuloma with peripheral circumscription and markedly degenerated ova; F: infected treated with Mef $(200 \mathrm{mg} / \mathrm{kg})+$ PZQ $(200 \mathrm{mg} / \mathrm{kg})$ showing small fibrocellular granuloma with more ova degeneration and less inflammatory cells; G: infected treated with Mef (400 mg/kg) + PZQ $(1,000 \mathrm{mg} / \mathrm{kg})$ showing small well demarcated granuloma with more fibrous tissue and less inflammatory cells (200X). 
$(\mathrm{p}<0.05, \mathrm{p}<0.01)$ alone at their reduced or high doses, respectively. Additionally, total protein levels were significantly elevated $(\mathrm{p}<0.05)$ in groups treated with either PZQ or Mef at high doses and albumin was significantly elevated $(p<0.01)$ in the group treated with a high dose of Mef. Treatment with PZQ + Mef in reduced and high doses completely normalised the total protein and albumin levels and the A/G ratio, while ALAT was still higher than normal (Table IV).

\section{DISCUSSION}

In the present study, we found that a dose of $200 \mathrm{mg} / \mathrm{kg}$ of Mef resulted in moderate reductions in the total number of mature and immature worms $(41.9 \%$ and $67.4 \%$, respectively) and $57.6 \%$ and $74.8 \%$ reductions in the number of mature and immature female worms, respectively. By increasing the dose of Mef to $400 \mathrm{mg} / \mathrm{kg}$, the reductions in the number of total mature and immature worms were increased to $67.7 \%$ and $89.9 \%$, respectively, with an $80.3 \%$ reduction in the number of mature females and a $96.8 \%$ reduction in the number of immature females. Nwaka and Hudson (2006) reported that Mef exceeds the benchmark criteria set forth by the World Health Organization (WHO) for highly active lead compounds, as they found a greater than $80 \%$ reduction in worm burden using the adult $S$. mansoni model and five consecutive Mef doses given intraperitoneally or subcutaneously. Keiser et al. (2009) exceeded the WHO criteria and showed that a single dose of Mef (200 mg/kg or $400 \mathrm{mg} / \mathrm{kg}$ ) administered orally to mice infected with either young developing or adult $S$. mansoni (Liberian strain) resulted in a high or complete reduction of the total and female worm burden
(72.3-100\%). In contrast, Nassauw et al. (2008) reported that a dose of $150 \mathrm{mg} / \mathrm{kg}$ of Mef had no effect on worm burden, but reduced egg fecundity in the first three developmental stages of $S$. mansoni in the murine model. The discrepancy between our study and the previous investigations may be due to differences in the strain of $S$. mansoni used and should be examined further.

It has been shown that female $S$. mansoni worms become fully mature, egg-producing worms on day 35 if they are paired on day 28 (Clegg 1965). Egg granulomas in livers and intestines are frequently detected from day 42 post infection onwards in mice (Miller et al. 1994). Therefore, at the time Mef was administered to $S$. mansoni-reinfected mice, adult schistosomes had been producing eggs for two weeks and granulomas had been present for one week. All mice were sacrificed 28 days after reinfection (56 days after the first infection) to ensure that all eggs and granulomatous reactions observed were due to the first infection. This allowed us to avoid confusion due to the presence of sub-patient and patient infections. Administration of Mef alone at both the reduced and high doses resulted in a remarkable decrease in the percentage of immature eggs and a reduction in the hepatic and intestinal egg counts with a corresponding increase in the percentage of dead eggs. This was associated with greater granuloma circumscription, more ova degeneration and fewer inflammatory cells. In addition, the serum levels of ALAT, total protein and albumin were significantly improved.

Administration of PZQ alone at both reduced and high doses resulted in a decrease in the mature worms (49\% and $92 \%$, respectively) that was greater than the de-

TABLE III

Effect of mefloquine (Mef) with/without praziquantel (PZQ) on granuloma diameter and associated histopathological changes nine weeks post-infection (i.e. 2 weeks post-treatment) in mice reinfected with Schistosoma mansoni

\begin{tabular}{|c|c|c|c|c|c|c|}
\hline \multirow[b]{2}{*}{ Animal groups } & \multirow[b]{2}{*}{ Granuloma diameter } & \multicolumn{3}{|c|}{ Types of granuloma } & \multicolumn{2}{|c|}{ State of $S$. mansoni eggs } \\
\hline & & $\begin{array}{l}\text { Cellular } \\
\quad(\%)\end{array}$ & $\begin{array}{c}\text { Fibrocellular } \\
(\%)\end{array}$ & $\begin{array}{c}\text { Fibrous } \\
(\%)\end{array}$ & Intact & Degenerated \\
\hline Infected untreated & $309.38 \pm 14.89$ & 20 & 80 & 0 & $89.62 \pm 0.53$ & $10.38 \pm 0.53$ \\
\hline $\begin{array}{l}\text { Inf + PZQ } \\
(200 \mathrm{mg} / \mathrm{kg})\end{array}$ & $\begin{array}{l}222.50 \pm 9.72^{a} \\
\quad(28.08)\end{array}$ & 0 & 100 & 0 & $13.00 \pm 1.60^{b}$ & $87.00 \pm 1.60^{b}$ \\
\hline $\begin{array}{l}\text { Inf + PZQ } \\
(1,000 \mathrm{mg} / \mathrm{kg})\end{array}$ & $\begin{array}{l}187.50 \pm 5.90^{b} \\
(39.39)\end{array}$ & 0 & 100 & 0 & $7.75 \pm 1.47^{b}$ & $92.25 \pm 1.47^{b}$ \\
\hline $\begin{array}{l}\text { Inf }+ \text { Mef } \\
(200 \mathrm{mg} / \mathrm{kg})\end{array}$ & $\begin{array}{l}228.12 \pm 15.17^{a} \\
\quad(26.26)\end{array}$ & 0 & 100 & 0 & $28.25 \pm 3.46^{b}$ & $71.75 \pm 3.46^{b}$ \\
\hline $\begin{array}{l}\text { Inf }+ \text { Mef } \\
(400 \mathrm{mg} / \mathrm{kg})\end{array}$ & $\begin{array}{l}208.75 \pm 26.42^{b} \\
\quad(32.53)\end{array}$ & 0 & 100 & 0 & $11.88 \pm 0.91^{b}$ & $88.12 \pm 0.91^{b}$ \\
\hline $\begin{array}{l}\text { Inf }+ \text { Mef + PZQ } \\
(200 \mathrm{mg} / \mathrm{kg}+200 \mathrm{mg} / \mathrm{kg})\end{array}$ & $\begin{array}{l}175.62 \pm 6.08^{b, d} \\
\quad(43.23)\end{array}$ & 0 & 100 & 0 & $7.50 \pm 1.85^{b, c}$ & $92.50 \pm 1.85^{b, c}$ \\
\hline $\begin{array}{l}\text { Inf }+ \text { Mef }+ \text { PZQ } \\
(400 \mathrm{mg} / \mathrm{kg}+1,000 \mathrm{mg} / \mathrm{kg})\end{array}$ & $\begin{array}{c}170.25 \pm 4.90^{b, e} \\
(44.97)\end{array}$ & 0 & 100 & 0 & $2.38 \pm 0.60^{b, f, g}$ & $97.62 \pm 0.60^{b, f, g}$ \\
\hline
\end{tabular}

$a: \mathrm{p}<0.01 ; b: \mathrm{p}<0.001$ vs. infected (Inf) untreated; $c: \mathrm{p}<0.05 ; d: \mathrm{p}<0.01$ vs. PZQ $(200 \mathrm{mg} / \mathrm{kg}) ; e: \mathrm{p}<0.05 ; f: \mathrm{p}<0.01 \mathrm{vs}$. PZQ $(1,000 \mathrm{mg} / \mathrm{kg}) ; g: \mathrm{p}<0.05 \mathrm{vs}$. PZQ + Mef $(200+200 \mathrm{mg} / \mathrm{kg})$. Number of animals in each group: eight mice. Values are presented as mean \pm standard error of the mean. Numbers between parentheses indicate the percentage of reduction from infected untreated. 
crease in immature worms ( $29 \%$ and $46 \%$, respectively) and a greater reduction was found in the number of males than females. These observations were associated with a high reduction of immature hepatic and intestinal eggs, an increase in the percentages of dead eggs and granuloma circumscription and improved ALAT and total protein serum levels. In this investigation, the therapeutic efficacy of PZQ was slightly higher than Mef with regard to all parameters studied, except for the lower efficacy of PZQ against young worm stages when used in its reduced $(29 \%)$ or higher $(46 \%)$ dose. Although there was an advantage for treatment with Mef over PZQ because it reduces both mature and immature worms $(68 \%$ and $90 \%$, respectively) with female reduction reaching $80-97 \%$, respectively, the efficacy of Mef against adult worms was not satisfactory (42-68\%) when used in its reduced and higher dose respectively. This may be due to the use of a dose that is sublethal to adult worms of the Egyptian strain, for which higher doses may be more effective. Additionally, Keiser et al. (2009) reported that the Mef treatment consistently resulted in a greater reduction in worm burden than PZQ when used against all development stages of the schistosome worms in the rodent model.

The use of Mef in combination with schistosomicidal agents that affect other stages of the parasite's life cycle may improve the treatment and control of schistosomiasis. Previous studies on the treatment of schistosomiasis with a combination of artemether and PZQ in humans and animals showed that combination therapy resulted in a significantly higher reduction in worm burden than administration of either drug alone (Utzinger et al. 2001, Xiao et al. 2002, Botros et al. 2007). In the present study, concomitant administration of PZQ + Mef at reduced doses exceeded the effect of the reduced PZQ dose alone, with combination therapy resulting in a very high reduction in the numbers of total mature $(95 \%$ vs. $49 \%$ ) and immature worms ( $96 \%$ vs. $29 \%$ ) and the complete eradication of immature and mature females as well as immature eggs. We also observed a high level of reduction in both hepatic and intestinal tissue egg loads and healing of hepatic granulomatous lesions, as evidenced by the presence of more degenerated eggs, more granuloma circum-

TABLE IV

Effect of mefloquine (Mef) with/without praziquantel (PZQ) on liver and kidney function tests in uninfected (Uninf) and Schistosoma mansoni-reinfected mice

\begin{tabular}{|c|c|c|c|c|c|c|}
\hline Animal groups & $\begin{array}{l}\text { ALAT } \\
(\mathrm{U} / \mathrm{mL})\end{array}$ & $\begin{array}{l}\text { Total protein } \\
(\mathrm{g} / 100 \mathrm{~mL})\end{array}$ & $\begin{array}{l}\text { Albumin } \\
(\mathrm{g} / 100 \mathrm{~mL})\end{array}$ & $\begin{array}{l}\text { Globulin } \\
(\mathrm{g} / 100 \mathrm{~mL})\end{array}$ & $\mathrm{A} / \mathrm{G}$ ratio & $\begin{array}{c}\text { Urea } \\
(\mathrm{mg} / \mathrm{dL})\end{array}$ \\
\hline Uninfected untreated & $55.83 \pm 6.11$ & $7.32 \pm 0.23$ & $4.15 \pm 0.08$ & $3.13 \pm 0.23$ & $1.38 \pm 0.12$ & $37.98 \pm 3.23$ \\
\hline $\begin{array}{l}\text { Uninf + PZQ } \\
(200 \mathrm{mg} / \mathrm{kg})\end{array}$ & $61.13 \pm 4.22$ & $7.08 \pm 0.27$ & $3.98 \pm 0.10$ & $3.15 \pm 0.21$ & $1.28 \pm 0.11$ & $44.33 \pm 4.16$ \\
\hline $\begin{array}{l}\text { Uninf }+ \text { PZQ } \\
(1,000 \mathrm{mg} / \mathrm{kg})\end{array}$ & $65.83 \pm 4.55$ & $6.98 \pm 0.28$ & $3.88 \pm 0.15$ & $3.10 \pm 0.39$ & $1.38 \pm 0.21$ & $43.83 \pm 3.22$ \\
\hline $\begin{array}{l}\text { Uninf }+ \text { Mef } \\
(200 \mathrm{mg} / \mathrm{kg})\end{array}$ & $59.19 \pm 5.16$ & $7.33 \pm 0.31$ & $3.78 \pm 0.18$ & $3.45 \pm 0.28$ & $1.11 \pm 0.18$ & $32.16 \pm 2.25$ \\
\hline $\begin{array}{l}\text { Uninf }+ \text { Mef } \\
(400 \mathrm{mg} / \mathrm{kg})\end{array}$ & $68.33 \pm 7.03$ & $6.55 \pm 0.31$ & $3.73 \pm 0.27$ & $2.75 \pm 0.33$ & $1.56 \pm 0.33$ & $41.93 \pm 2.95$ \\
\hline $\begin{array}{l}\text { Uninf }+ \text { Mef }+ \text { PZQ } \\
(200 \mathrm{mg} / \mathrm{kg}+200 \mathrm{mg} / \mathrm{kg})\end{array}$ & $56.43 \pm 6.15$ & $6.83 \pm 0.33$ & $4.11 \pm 0.12$ & $2.73 \pm 0.27$ & $1.52 \pm 0.22$ & $37.42 \pm 2.18$ \\
\hline $\begin{array}{l}\text { Uninf }+ \text { Mef }+ \text { PZQ } \\
(400 \mathrm{mg} / \mathrm{kg}+1,000 \mathrm{mg} / \mathrm{kg})\end{array}$ & $69.17 \pm 6.11$ & $6.92 \pm 0.32$ & $3.83 \pm 0.22$ & $2.76 \pm 0.17$ & $1.43 \pm 0.08$ & $44.43 \pm 3.47$ \\
\hline Infected untreated & $162.22 \pm 6.19^{c}$ & $6.28 \pm 0.18^{b}$ & $3.12 \pm 0.16^{c}$ & $3.16 \pm 0.11$ & $1.01 \pm 0.07^{a}$ & $45.01 \pm 2.49$ \\
\hline $\begin{array}{l}\text { Inf + PZQ } \\
(200 \mathrm{mg} / \mathrm{kg})\end{array}$ & $114.37 \pm 8.29^{c, e}$ & $6.55 \pm 0.15^{a}$ & $3.3 \pm 0.23^{b}$ & $3.25 \pm 0.23$ & $1.06 \pm 0.12$ & $44.01 \pm 2.85$ \\
\hline $\begin{array}{l}\text { Inf + PZQ } \\
(1,000 \mathrm{mg} / \mathrm{kg})\end{array}$ & $83.37 \pm 4.85^{b, f}$ & $6.78 \pm 0.25^{d}$ & $3.42 \pm 0.17^{b}$ & $3.51 \pm 0.24$ & $1.01 \pm 0.10^{a}$ & $45.99 \pm 4.24$ \\
\hline $\begin{array}{l}\text { Inf }+ \text { Mef } \\
(200 \mathrm{mg} / \mathrm{kg})\end{array}$ & $139.38 \pm 6.30^{c, d}$ & $6.19 \pm 0.40$ & $3.35 \pm 0.20^{\mathrm{a}}$ & $2.84 \pm 0.24$ & $1.21 \pm 0.09$ & $46.04 \pm 4.20$ \\
\hline $\begin{array}{l}\text { Inf }+ \text { Mef } \\
(400 \mathrm{mg} / \mathrm{kg})\end{array}$ & $117.86 \pm 13.75^{b, e}$ & $6.86 \pm 0.17^{d}$ & $3.76 \pm 0.10^{b, e}$ & $3.10 \pm 0.19$ & $1.24 \pm 0.08$ & $37.37 \pm 5.18$ \\
\hline $\begin{array}{l}\text { Inf }+ \text { Mef }+ \text { PZQ } \\
(200 \mathrm{mg} / \mathrm{kg}+200 \mathrm{mg} / \mathrm{kg})\end{array}$ & $91.11 \pm 6.86^{b, g}$ & $6.80 \pm 0.24$ & $3.79 \pm 0.19$ & $2.90 \pm 0.24$ & $1.38 \pm 0.12$ & $32.84 \pm 2.56$ \\
\hline $\begin{array}{l}\text { Inf }+ \text { Mef + PZQ } \\
(400 \mathrm{mg} / \mathrm{kg}+1,000 \mathrm{mg} / \mathrm{kg})\end{array}$ & $79.25 \pm 5.83^{a}$ & $7.12 \pm 0.32$ & $3.83 \pm 0.18$ & $3.28 \pm 0.27$ & $1.24 \pm 0.13$ & $37.38 \pm 2.72$ \\
\hline
\end{tabular}

$a: \mathrm{p}<0.05 ; b: \mathrm{p}<0.01 ; c: \mathrm{p}<0.001$ vs. uninfected untreated; $d: \mathrm{p}<0.05 ; e: \mathrm{p}<0.01 ; f: \mathrm{p}<0.001$ vs. infected (Inf) untreated; $g: \mathrm{p}$ $<0.05$ vs. Inf + PZQ (200 mg/kg); A/G: albumin/globulin; ALAT: alanine aminotransferase. Number of animals in each group: eight mice. Values are presented as mean \pm standard error of the mean. 
scription, fewer inflammatory cells and normal levels of all tested liver enzymes. These effects are likely due to the dual actions of both the antimalarial Mef on the schistosomula and adult stages of the worm and the schistosomicidal PZQ on the adult stages of schistosome worms.

Interestingly, no noticeable differences in the therapeutic efficacy were observed between the reduced and high doses of PZQ + Mef. Previous investigations on the morphology of schistosomes recovered from host animals after administration of PZQ (Mehlhorn et al. 1981) and observations made with schistosomes recovered from Mef-treated mice indicate different mechanisms of action (Keiser et al. 2009). Mef rapidly affects schistosomes, resulting in marked alterations of the digestive tract and the reproductive system of the adult worms. However, a direct effect of Mef on S. mansoni eggs cannot be excluded (Von Lichtenberg 1962). Although nothing is known about the presence or expression of P-glycoprotein (P-gp) in S. mansoni eggs, P-gp has been observed in the external layers of the shells of eggs of the red stomach worm Haemonchus contortus, a parasitic nematode of ruminants, suggesting that $\mathrm{P}$-gp inhibition might contribute to the elimination of parasitic eggs (Riou et al. 2005).

Concerning the safety of both drugs, no side effects were observed for either dose of both drugs in the host animals. Animal behaviour was normal with $0 \%$ mortality. Liver and kidney function tests remained within the normal limits and liver histology showed no hydropic, steatotic, feathery or ballooning changes, degeneration or apoptosis. Only scattered or focal collections of lymphocytes between the hepatocytes (focal spotty necrosis) were observed in liver sections of uninfected mice treated with a high dose of Mef alone or combined with a high dose of PZQ. In general, the toxicity of PZQ was very low in both short and long-term experiments (Frohberg 1984). Some adverse reactions are likely due to the release of cellular contents from dying schistosomes. This may well be the case with the most severe side effects, such as bloody diarrhoea or oedematous urticarial, which are encountered mainly in endemic areas (Polderman et al. 1984). Mef is generally well tolerated by adults and children; however, there is evidence that Mef may harm the gastrointestinal and central nervous systems (AlKadi 2007). Adverse reactions to Mef include insomnia, nausea, vomiting, diarrhoea, headache, dizziness, rash, pruritus and abdominal pain (AlKadi 2007). In addition, Nassauw et al. (2008) reported that Mef induces a severe mastocytosis in the intestinal wall, leading to intestinal inflammation and gastrointestinal disturbances due to mast cell recruitment to the intestine. This can result in visceral pain and disturb the motor and secretory functions of the intestine. Moreover, the neurotoxicity of Mef cannot be explained (Pham et al. 1999). Another aspect worth mentioning when considering PZQ-Mef combination therapy is the argument that the antimalarial drugs should not be recommended for chemoprophylaxis or treatment of schistosomiasis in areas where malaria is co-endemic because of the risk of resistance development in the malaria parasites. This warrants further investigation into the mechanisms of Mef resistance.
In conclusion, Mef significantly reduces both worm burden (immature and mature) and egg production and returns liver histology and function to normal levels. The concomitant use of PZQ with Mef in reduced doses showed enhanced therapeutic efficacy compared with that of each drug alone. This was evidenced by the nearly complete eradication of immature worms, mature worms and eggs, healing of hepatic granulomatous lesions and normalisation of liver serum enzyme levels. Mef is safe at both doses $(200 \mathrm{mg} / \mathrm{kg}$ and $400 \mathrm{mg} / \mathrm{kg})$ whether used alone or in combination with PZQ. Accordingly, Mef could be used at a low dose in combination with a reduced dose of PZQ for the treatment of human schistosomiasis, thus potentially preventing treatment failures in areas with high rates of transmission. Therefore, the combination therapy may represent a cost-effective treatment regimen in developing countries.

\section{REFERENCES}

Abdulla MH, Lim KC, Sajid M, McKerrow JH, Caffrey CR 2007. Schistosomiasis mansoni: novel chemotherapy using a cysteine protease inhibitor. PLoS Med 4: e14.

AlKadi HO 2007. Antimalarial drug toxicity: a review. Chemotherapy 53: 385-391.

Botros S, Sayed H, Amer N, El-Ghannam M, Bennett JL, Day TA 2005. Current status of sensitivity to praziquantel in a focus of potential drug resistance in Egypt. Int J Parasitol 35: 787-791.

Botros SS, Bennett JL 2007. Praziquantel resistance. Expert Opin Drug Discov 2 (Suppl. 1): S35-S40.

Botros SS, Mahmoud MR, Moussa MM, Nosseir MM 2007. Immunohistopathological and biochemical changes in Schistosoma mansoni-infected mice treated with artemether. J Infect 55: 470-477.

Caffrey CR 2007. Chemotherapy of schistosomiasis: present and future. Curr Opin Chem Biol 11: 433-439.

Cheever AW 1968. Conditions affecting the accuracy of potassium hydroxide digestion techniques for counting Schistosoma mansoni eggs in tissues. Bull World Health Organ 39: 328-331.

Clegg JA 1965. In vitro cultivation of Schistosoma mansoni. Exp Parasitol 16: 133-147.

Doenhoff M, Cioli D, Utzinger J 2008. Praziquantel: mechanisms of action, resistance and new derivatives for schistosomiasis. Curr Opin Infect Dis 21: 659-667.

Duvall RH, De Witt WB 1967. An improved perfusion technique for recovering adult schistosomes from laboratory animals. $\mathrm{Am} \mathrm{J}$ Trop Med Hyg 16: 483-486.

Engels D 2002. The global epidemiological situation of schistosomiasis and new approaches to control and research. Acta Trop 82: 139-146.

Fallon PG, Doenhoff MJ 1995. Active immunization of mice with Schistosoma mansoni worm membrane antigens enhances efficacy of praziquantel. Parasite Immunol 7: 261-268.

Fenwick A 2003. Drugs for the control of parasitic diseases: current status and development in schistosomiasis. Trends Parasitol 19: 509-515.

Fenwick A, Webster JP 2006. Schistosomiasis: challenges for control, treatment and drug resistance. Curr Opin Infect Dis 19: 577-582.

Frohberg H 1984. Results of toxicological studies on praziquantel. Arzneimittelforschung 4: 1137-1144.

Geary TG, Woo K, McCarthy JS, Mackenzie CD, Horton J, Prichard RK, de Silva NR, Olliaro PL, Lazdins-Helds JK, Engels DA, 
Bundy DA 2010. Unresolved issues in anthelmintic pharmacology for helminthiases of humans. Int J Parasitol 40: 1-13.

Gonnert R, Andrews P 1977. Praziquantel, a new broad spectrum antischistosomal agent. Z Parasitenkd 52: 129-150.

Ismail M, Botros S, Metwally A, William S, Farghally A, Tao LF, Day TA, Bennett JL 1999. Resistance to praziquantel: direct evidence from Schistosoma mansoni isolated from Egyptian villagers. Am J Trop Med Hyg 60: 932-935.

Ismail M, Metwally A, Farghaly A, Bruce J, Tao LF, Bennett JL 1996. Characterization of isolates of Schistosoma mansoni from Egyptian villagers that tolerate high doses of praziquantel. Am J Trop Med Hyg 55: 214-418.

Keiser J, Chollet J, Xiao S, Mei J, Jiao P, Utzinger J, Tanner M 2009. Mefloquine - an aminoalcohol with promising antischistosomal properties in mice. PLOS Negl Trop Dis 3: e350.

Keiser J, Utzinger J 2007. Artemisinins and synthetic trioxolanes in the treatment of helminth infections. Curr Opin Infect Dis 20: 605-612.

King CH, Dickman K, Tisch DJ 2005. Reassessment of the cost of chronic helminthic infection: a meta-analysis of disability-related outcomes in endemic schistosomiasis. Lancet 365: 1561-1569.

Liang YS, John BI, Boyd DA 1987. Laboratory cultivation of schistosome vector snails and maintenance of schistosome life cycles. Proceeding of the 1st Sino-American Symposium 1: 34-48.

Mehlhorn H, Becker B, Andrews P, Thomas H, Frenkel JK 1981. In vivo and in vitro experiments on the effects of praziquantel on Schistosoma mansoni: a light and electron microscopic study. Arzneimittelforschung 31: 544-554.

Miller HRP, Newlands GFJ, McKellar A, Inglis L, Coulson PS, Wilson RA 1994. Hepatic recruitment of mast cells occurs in rats but not in mice infected with Schistosoma mansoni. Parasite Immunol 16: 145-155.

Nassauw LV, Toovey S, Van Op den bosch J, Jean-Pierre, Timmermans J 2008. Schistosomicidal activity of the antimalarial drug, mefloquine, in Schistosoma mansoni-infected mice. Travel Med Infect Dis 6: 253-258.

Nwaka S, Hudson A 2006. Innovative lead discovery strategies for tropical diseases. Nat Rev Drug Discov 5: 941-955.

Pellegrino J, Oliveira CA, Faria J, Cunha AS 1962. New approach to the screening of drugs in experimental schistosomiasis mansoni in mice. Am J Trop Med Hyg 11: 201-215.

Pham YT, Nosten F, Farinotti R, White NJ, Gimenez F 1999. Cerebral uptake of mefloquine enantiomers in fatal cerebral malaria. Int $J$ Clin Pharmacol Ther 37: 58-61.

Polderman AM, Gryseels B, Gerold JL, Mpamila K, Manshande JP 1984. Side effects of praziquantel in the treatment of Schistosoma mansoni in Maniema, Zaire. Trans R Soc Trop Med Hyg 78: $752-754$.
Riou M, Koch C, Delaleu B, Berthon P, Kerboeuf D 2005. Immunolocalisation of an $\mathrm{ABC}$ transporter, P-glycoprotein, in the eggshells and cuticles of free-living and parasitic stages of Haemonchus contortus. Parasitol Res 96: 142-148.

Sabah AA, Fletcher C, Webbe G, Doenhoff MG 1986. Schistosoma mansoni: chemotherapy of infections of different ages. Exp Parasitol 61: 294-303.

Sayed AA, Simeonov A, Thomas CJ, Inglese J, Austin CP, Williams DL 2008. Identification of oxadiazoles as new drug leads for the control of schistosomiasis. Nat Med 4: 407-412.

Seif el-Din SH 2007. Prophylactic effect of artesunate with/without antioxidants on juvenile and adult Egyptian strain of Schistosoma mansoni in mice. Az J Pharm Sci 35: 80-93.

Steinmann P, Keiser J, Bos R, Tanner M, Utzinger J 2006. Schistosomiasis and water resources development: systematic review, meta-analysis and estimates of people at risk. Lancet Infect Dis 6: 411-425.

Utzinger J, Shuhua X, N'Goran EK, Bergquist R, Tanner M 2001. The potential of artemether for the control of schistosomiasis. Int $J$ Parasitol 31: 1549-1562.

Utzinger J, Xiao SH, Tanner M, Keiser J 2007. Artemisinins for schistosomiasis and beyond. Curr Opin Investig Drugs 8: 105-116.

Von Lichtenberg FC 1962. Host response to eggs of Schistosoma mansoni. I. Granuloma formation in the sensitized laboratory mouse. Am J Pathol 41: 711-731.

White NJ 2008. Qinghaosu (artemisinin): the price of success. Science 320: 330-334.

WHO - World Health Organization 2000. Report of the WHO informal consultation on schistosomiasis in low transmission areas: control strategies and criteria for elimination, WHO, London, $56 \mathrm{pp}$.

Xiao SH, Booth M, Tanner M 2000. The prophylactic effects of artemether against Schistosoma japonicum infections. Parasitol Today 16: 122-126.

Xiao SH, Keiser J, Chollet J, Utzinger J, Dong Y, Endriss Y, Vennerstrom JL, Tanner M 2007. The in vitro and in vivo activities of synthetic trioxolanes on major human schistosome species. Antimicrob Agents Chemother 51: 1440-1445.

Xiao SH, Mei JY, Jiao PY 2009. The in vitro effect of mefloquine and praziquantel against juvenile and adult Schistosoma japonicum. Parasitol Res 106: 237-246.

Xiao SH, Mei JY, Jiao PY 2011. Effect of mefloquine administered orally at single, multiple or combined with artemether, artesunate or praziquantel in treatment of mice infected with. Schistosoma japonicum. Parasitol Res 108: 399-406.

Xiao SH, Tanner M, N'Goran EK, Utzinger J, Chollet J, Bergquist R, Chen M, Zheng J 2002. Recent investigations of artemether, a novel agent for the prevention of schistosomiasis japonica, mansoni and haematobia. Acta Trop 82: 175-181. 